\title{
RANCANG BANGUN SISTEM PENDETEKSI TINGGI BADAN DAN ANTRIAN OTOMATIS PADA PINTU MASUK WAHANA BERMAIN
}

\author{
Dandy Permana Putra ${ }^{1}$, \\ Program Studi Broadband Multimedia Politeknik Negeri Jakarta \\ Email: dandy.permanaputera@gmail.com \\ Agus Wagyana $^{1}$ \\ Program Studi Broadband Multimedia Politeknik Negeri Jakarta \\ Email: awagyana@gmail.com
}

\begin{abstract}
S : The amusement rides, has a height limit for riding a rides. The regulation was made for security and safety when riding a rides. In dangerous amusement rides, height regulation is made with a minimum height with a high enough number, the height limit can be above $130 \mathrm{~cm}$. The limit makes many visitors can't ride rides because they have less height. But even though the regulation has been made, there are still many visitors who still want to ride the amusement rides even though its height is insufficient. Therefore, it would be more effective if an automatic door was made that could detect the height of the visitor's and the door would open if the visitor's had a sufficient height. This door is placed in the position before the queue, so in addition to the automatic door, there is also a system of counting the number of visitors who are in the queue. The number of queues will be displayed on the seven segment screen and if the queue is full it will be informed on the LCD. The height limit on this door is made with a minimum height of $130 \mathrm{~cm}$ so that the door is open. This door height and automatic queuing system uses the Arduino Mega microcontroller and the FC-51 infrared obstacle sensor to detect visitors. Besides this door is equipped with LEDs and loudspeakers as a provider of information about the visitors of the amusement rides is allowed to enter or not due to the height of the visitor's.
\end{abstract}

Keywords : Arduino Mega, Infrared sensor, Door, Amusement Rides, Height.

\begin{abstract}
ABSTRAK : Sebuah wahana bermain, memiliki peraturan batas tinggi badan untuk menaiki wahana. Peraturan tersebut dibuat demi keamanan dan keselamatan saat menaiki suatu wahana. Dalam wahana yang berbahaya, peraturan batas tinggi badan dibuat dengan tinggi minimal dengan angka yang cukup tinggi, batas tinggi bisa berupa diatas $130 \mathrm{~cm}$. Batas tersebut membuat banyak pengunjung wahana tidak bisa menaiki wahana karena memiliki tinggi yang kurang. Walaupun peraturan tersebut sudah dibuat, masih banyak pengunjung wahana yang tetap ingin menaiki wahana walaupun tinggi nya kurang mencukupi. Oleh karena itu, akan lebih efektif jika dibuat sebuat pintu otomatis yang dapat mendeteksi tinggi badan pengunjung wahana dan pintu akan terbuka jika pengunjung wahana memiliki tinggi yang cukup. Pintu ini diletakan pada posisi sebelum antrian, maka selain pintu otomatis, juga ada sistem penghitung jumlah pengunjung yang berada didalam antrian. Jumlah antrian akan ditampilkan di layar seven segment dan jika antrian penuh akan diinformasikan pada LCD. Batas tinggi badan pada pintu ini dibuat dengan tinggi minimal $130 \mathrm{~cm}$ agar pintu terbuka. Sistem pintu pengukur tinggi dan antrian otomatis ini menggunakan mikrokontoler Arduino Mega serta sensor infrared obstacle FC-51 untuk mendeteksi adanya pengunjung. Selain itu pintu ini dilengkapi dengan LED dan loudspeaker sebagai pemberi informasi tentang pengunjung wahana diperbolehkan untuk masuk atau tidak dikarenakan tinggi badan pengunjung wahana.
\end{abstract}

Kata kunci : Arduino Mega, Sensor Infrared, Pintu, Wahana Bermain, Tinggi Badan.

\section{PENDAHULUAN}

Setiap wahana bermain memiliki peraturan batas tinggi untuk menaikinya. Dalam sebuah wahana yang berbahaya dan extreme membutuhkan tinggi tertentu untuk menaiki sebuah wahana. Karena beberapa wahana biasanya dibuat dengan sistem pengamanan yang rata-ratanya membutuhkan tinggi yang cukup.

Hal tersebut menjadikan banyak anak-anak atau orang yang tidak tinggi menjadi tidak dapat menaiki wahana. Banyak anak-anak atau orang yang tidak tinggi tetap menaiki wahana yang extreme walaupun tingginya belum mencukupi. Hal itu sangat berbahaya bagi keselamatan hidup. Dikarenakan tidak ketatnya peraturan tentang tinggi badan di wahana dan masih banyak yang menerobos masuk wahana walaupun tingginya kurang mencukupi, maka bisa dibuat inovasi tentang pengukuran tinggi badan pada pintu masuk antrian.

Berdasarkan hal-hal tersebut dapat dibuat sebuah sistem yang dapat menjadi solusi dari masalah tersebut dengan judul "Rancang Bangun Sistem Pendeteksi Tinggi Badan dan Antrian Otomatis Pada Pintu Masuk Wahana Bermain" yang kedepannya dapat berguna bagi keamanan dan keselamatan para pengguna wahana, dan mengurangi tingkat terjadinya kecelakaan pada wahana. Penulisan ini bertujuan untuk memperoleh sebuah pintu pendeteksi tinggi dan penghitung antrian

\footnotetext{
${ }^{1}$ Program Studi Broadband Multimedia Politeknik Negeri Jakarta
} 
otomatis yang akan menjadikan peraturan tinggi badan lebih ketat lagi sehingga pengunjung yang memiliki tinggi yang kurang tidak bisa menerobos masuk antrian.

Sistem pendeteksi tinggi badan akan diterapkan pada pintu masuk wahana bermain dengan ukuran tinggi $20 \mathrm{~cm}$ dan lebar $10 \mathrm{~cm}$, batas tinggi untuk pengunjung yang dapat memasuki wahana yaitu $130 \mathrm{~cm}$ dibuat dengan skala 1:10 menjadi $13 \mathrm{~cm}$.

\section{Wahana Bermain}

\section{TINJAUAN PUSTAKA}

Wahana adalah alat yang berupa sarana yang memiliki tujuan tertentu seperti wahana permainan yang berarti sarana atau alat yang digunakan untuk bermain [1]. Pada suatu wahana permainan pada tempat rekreasi seperti Dunia Fantasi, Trans Studio, Jungle Land dan lain lain, selalu terdapat wahana yang mengharuskan pengunjung mempunya tinggi badan yang sudah ditetapkan untuk alasan keselamatan. Karena itu pada gerbang pintu wahananya tersebut biasanya terdapat penjaga yang mengawasi dan menyeleksi para pengunjung yang bisa memasuki wahana tersebut, proses penyeleksian itu kadang berjalan lambat dikarenakan pengukuran yang manual. Bahkan untuk sekarang sudah tidak ada lagi penjaga yang mengawas, maka dari itu wahana wahana ditempat rekreasi masih butuh pengamanan dan peraturan tinggi badan yang ketat.

\section{Mikrokontroler}

Mikrokontroler adalah sebuah mini processor yang digunakan dalam sebuah sistem pengontrolan yang memiliki fisik yang sangat kecil dari pada sebuah komputer personal dan dirancang dengan memiliki elemen dasar yang serupa, walaupun dengan ukurannya yang sangat kecil [2].

\section{Pemograman Arduino}

Arduino dikatakan sebagai sebuah platform dari physical computing yang bersifat open source baik secara hardware dan software [3]. Arduino tidak hanya sekedar sebuah alat pengembangan, tetapi kombinasi dari hardware, bahasa pemrograman dan Integrated Development Environment (IDE) yang canggih.

Bahasa pemrograman Arduino pada dasarnya menggunakan bahasa pemograman $\mathrm{C}$, bahasa $\mathrm{C}$ sendiri merupakan bahasa tingkat tinggi yang sangat populer dan banyak digunakan oleh para programmer [3]. Dengan demikian aturan penulisan dan penggunaan dari bahasa Arduino akan sama dengan bahasa C. Untuk mempelajari lebih jauh lagi bahasa pemograman Arduino dan perintahperintah apa saja yang ada pada bahasa pemrograman Arduino kamu bisa membuka disitus resmi Arduino Reference atau mengaksesnya dalam bentuk aplikasi Android kamu bisa download Arduino Language Reference.

\section{Arduino Mega}

Board Arduino Mega 2560 adalah sebuah board Arduino yang menggunakan IC Mikrokontroler ATmega 2560 dan memiliki Pin I/O yang relatif banyak, 54 digital Input / Output, 15 buah diantaranya dapat digunakan sebagai output PWM, 16 buah analog input, 4 UART [4].

Arduino Mega 2560 dilengkapi kristal $16 \mathrm{Mhz}$. Untuk penggunaan relatif sederhana, penggunaan dapat dilakukan dengan menghubungkan power dari USB ke PC / Laptop atau melalui Jack DC menggunakan adaptor 7-12 V DC.

Arduino Mega seperti yang diperlihatkan pada Gambar 1 memiliki jumlah pin yang lebih banyak dibandingkan dengan Arduino lainnya.

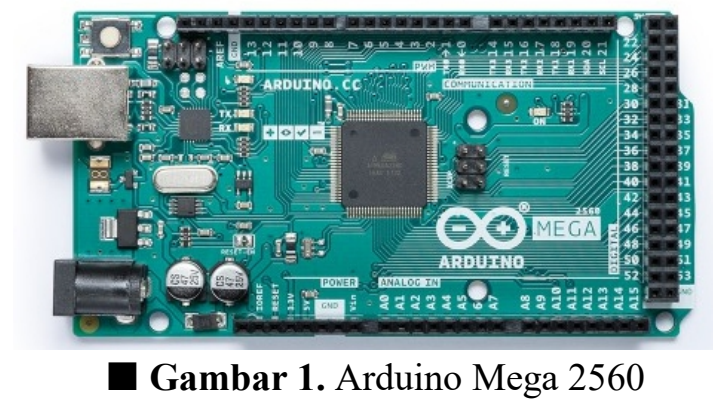


IR Obstacle Sensor infrared merupakan sebuah modul yang berfungsi sebagai pendeteksi halangan atau object di depannya [5]. Contoh penggunaanya pada alarm yang berbunyi, saat sesuatu mendekat, atau mengubah arah robot ketika mendekati dinding dan bisa digunakan untuk sistem pendeteksian. Sensor ini memiliki tiga kaki pin untuk power supply, ground dan digital input Arduino seperti yang diperlihatkan pada Gambar 2 .

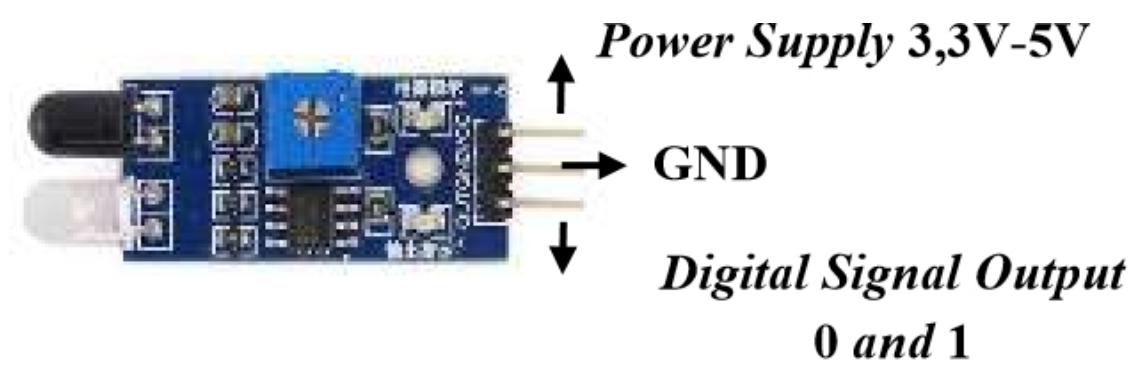

Gambar 2. Sensor IR Obstacle

\section{Motor Servo}

Motor servo atau mikro servo merupakan motor listrik dengan sistem umpan balik tertutup dimana posisi dari motor akan diinformasikan kembali ke rangkaian kontrol yang ada di dalam motor servo [6]. Motor ini terdiri dari sebuah motor DC, serangkaian gear, potensiometer, dan rangkaian kontrol. Potensiometer berfungsi untuk menentukan batas sudut dari putaran servo. Sedangkan sudut dari sumbu motor servo diatur berdasarkan lebar pulsa yang dikirimkan melalui sinyal dari sebuah kabel motor.

\section{LCD}

LCD (Liquid Cristal Display) merupakan salah satu jenis Display elektronik yang dibuat dengan teknologi CMOS logic yang bekerja dengan tidak menghasilkan cahaya tetapi memantulkan cahaya yang ada di sekelilingnya terhadap front-lit atau mentransmisikan cahaya dari back-lit [7]. LCD (Liquid Cristal Display) berfungsi sebagai penampil data baik dalam bentuk karakter, huruf, angka ataupun grafik.

\section{LED}

LED adalah komponen elektronika yang dapat memancarkan cahaya monokromatik ketika diberikan tegangan maju [8]. LED merupakan keluarga dioda yang terbuat dari bahan semikonduktor. LED juga dapat memancarkan sinar inframerah yang tidak tampak oleh mata seperti yang sering di jumpai pada remote control perangkat elektronik

\section{Seven Segment}

Seven segment yang digunakan untuk alat ini yaitu seven segment dua digit. Seven segment Display memiliki 7 Segmen dimana setiap segmen dikendalikan secara ON dan OFF untuk menampilkan angka yang diinginkan. Angka-angka dari 0 (nol) sampai 9 (Sembilan) dapat ditampilkan dengan menggunakan beberapa kombinasi Segmen [9].

\section{Loudspeaker}

Loudspeaker adalah sebuah Hardware yang termasuk output device serta mempunyai fungsi sebagai pengeluar suara yaitu dengan cara menangkap gelombang listrik dan merubahnya menjadi getaran suara [10].

\section{DFPlayerMini}

DFPlayer mini adalah modul mp3 yang outputnya sederhana, dapat langsung diaplikasikan pada pengeras suara speaker [11]. DFPlayer mini dapat digunakan dengan cara berdiri tunggal menggunakan baterai, speaker, dan push button, juga dapat digunakan pada Arduino Uno ataupun dengan perangkat lain yang memiliki kemampuan receiver atau transmitter. 
Sistem pendeteksi tinggi badan dan antrian otomatis pada pintu masuk wahana bermain ini memiliki dua bagian sistem kerja yaitu bagian sistem pendeteksi tinggi badan dan bagian sistem penghitung antrian. Kedua bagian tersebut menggunakan Arduino Mega 2560 sebagai mikrokontroler serta sensor infrared obstacle FC-51 sebagai komponen input. Sensor mengendalikan beberapa komponen output yaitu LCD yang berfungsi untuk menampilkan teks informasi berupa kalimat penyambutan dan informasi saat antrian penuh. LED sebagai lampu indikator penanda ketinggian. Motor servo sebagai penggerak pintu. Loudspeaker yang terhubung dengan modul DFPlayer Mini sebagai pemutar file audio mp3 yang berisi suara informasi tentang tinggi badan pengunjung wahana. Serta seven segment sebagai display jumlah antrian. Gambar 3 menunjukan diagram blok sistem.

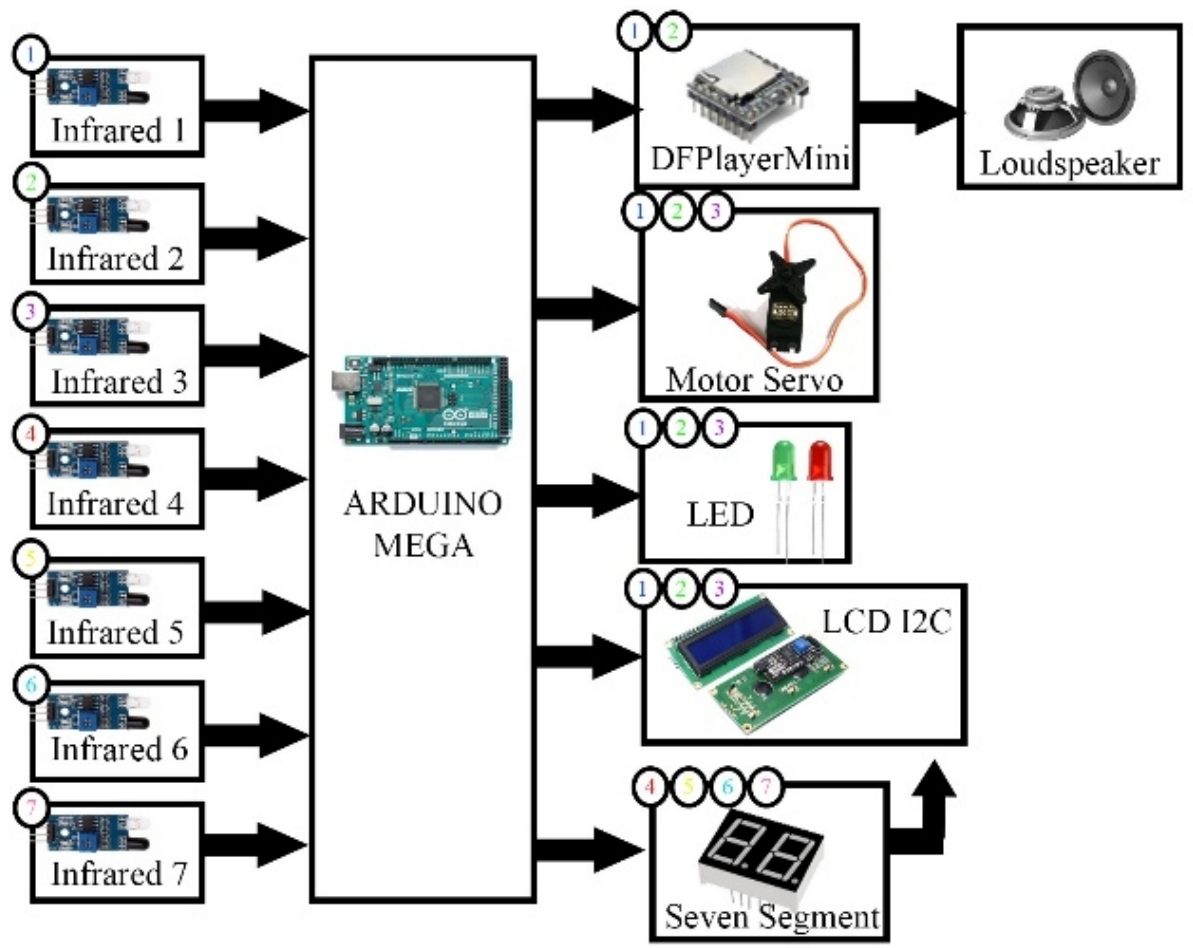

Gambar 3. Diagram Blok

Alat ini menggunkan tujuh buah sensor infrared obstacle FC-51 sebagai komponen input yang mempunyai fungsi masing-masing dan mengendalikan komponen output yang berbeda-beda pada setiap sensor. Cara kerja sistem ini digambarkan melalui flowchart yang diperlihatkan pada Gambar 4. 


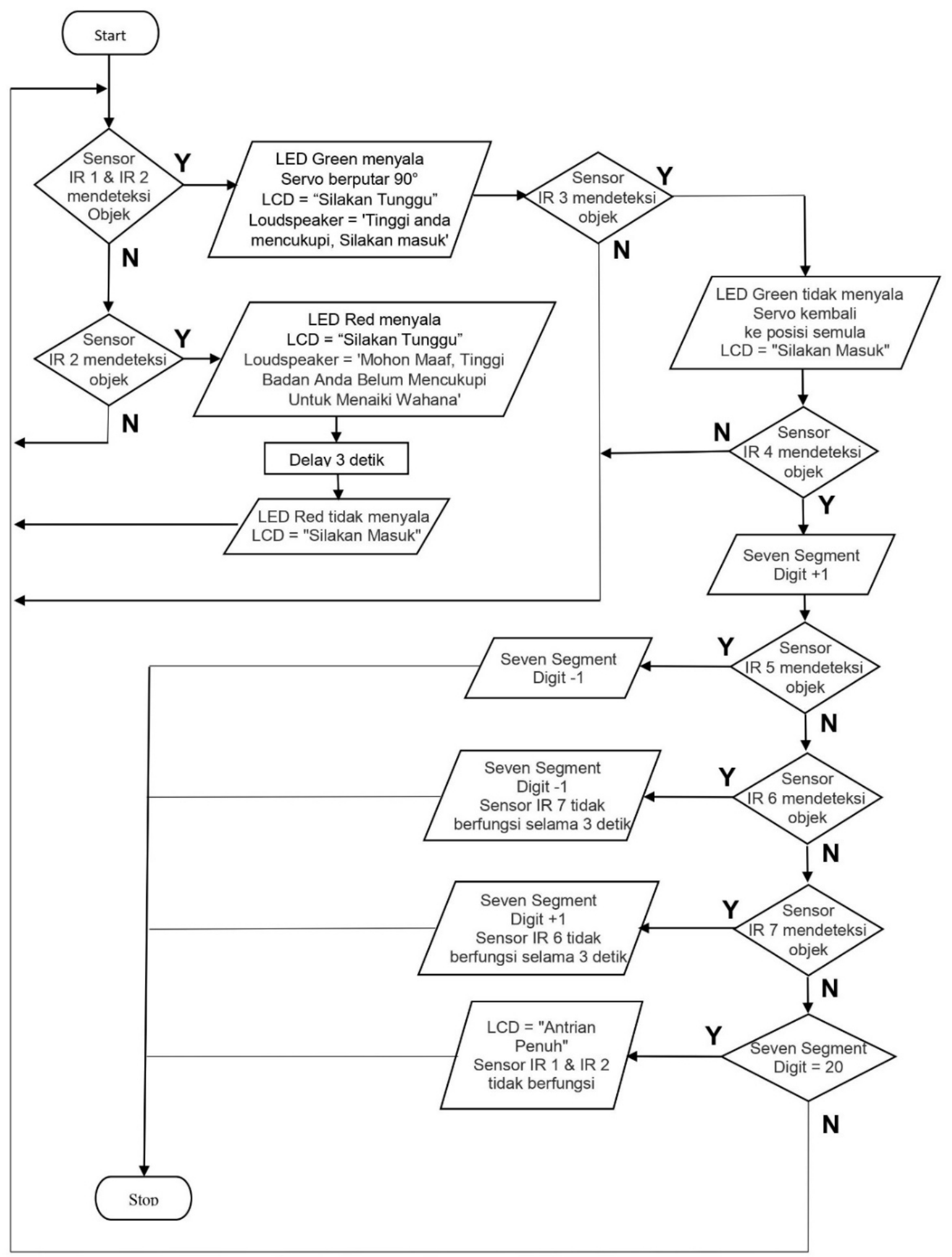

Gambar 4. Flowchart Cara Kerja

Visualisasi alat yang diperlihatkan pada Gambar 5 menunjukan jika pada bagian awal untuk pengunjung masuk, pengunjung akan melihat sebuat layar LCD yang disimpan di bagian atas pintu dan sebuah seven segment yang akan menampilkan jumlah orang yang ada di dalam antrian. Tampilan seven segment ini dikendalikan oleh sensor Infrared yang ke 4, 5, 6 dan 7 sebagai penghitung antrian. Setelah pengunjung masuk dan berhasil masuk maka pintu akan terbuka, pintu dikendalikan oleh motor servo. Motor servo, led, led serta loudspeaker dikendalikan oleh sensor Infrared yang ke 1, 2 dan 3 sebagai pintu pengukur tinggi. 


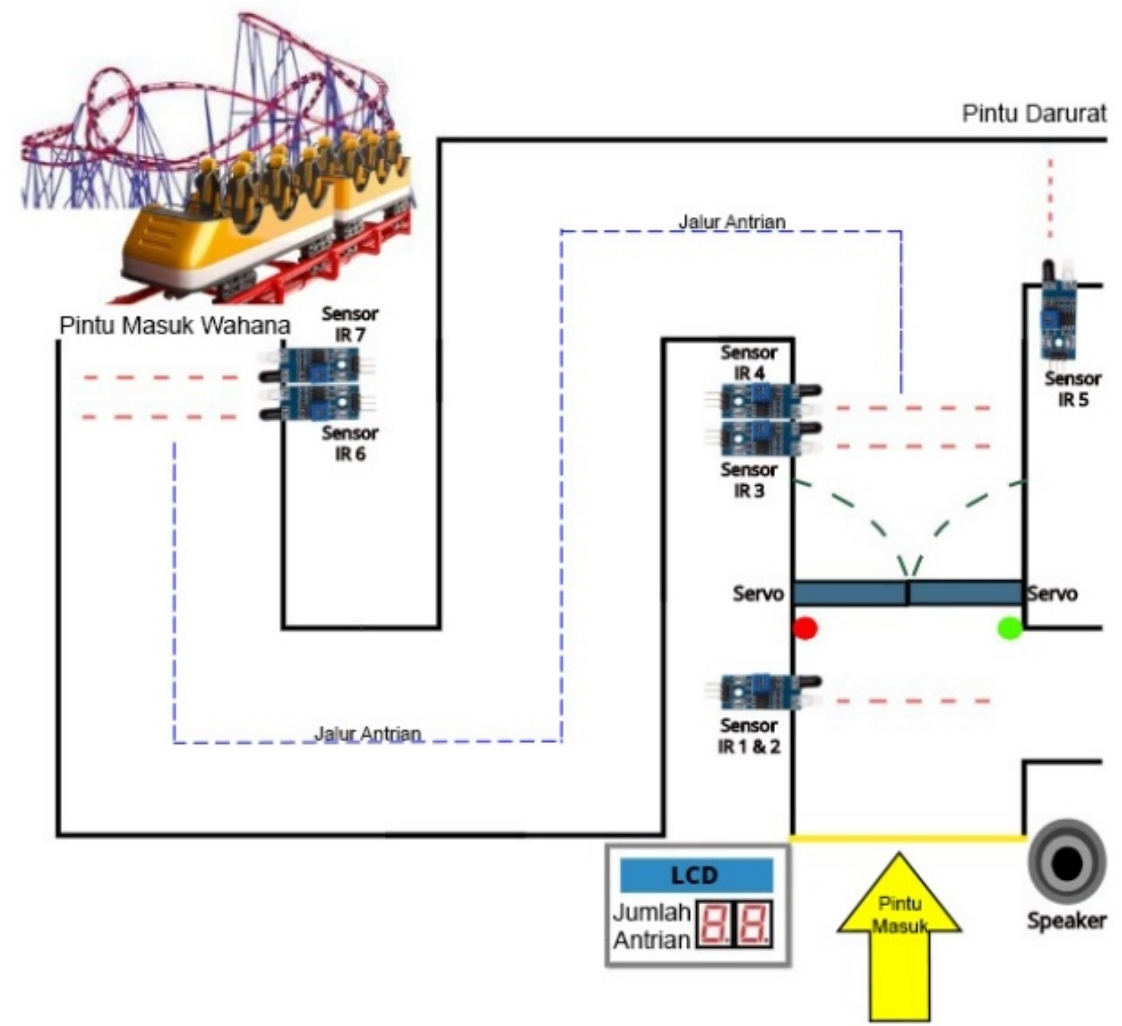

Gambar 5. Visualisasi Alat

Langkah-langkah proses dalam pembuatan alat dan penelitian yang dilakukan adalah :

1. Menentukan pin komponen yang terhubung ke mikrokontroler Arduino,

2. Menghubungkan komponen ke rangkaian alat,

3. Menghubungkan power adaptor ke rangkaian alat,

4. Melakukan pengukuran jarak deteksi, tegangan sensor, jenis obstacle dan response time sensor.

5. Mengambil data hasil pengukuran dan membuat tabel data pengujian.

6. Menganalisis hasil data yang telah didapatkan.

\section{HASIL DAN PEMBAHASAN}

Terdapat 3 pengujian yaitu pengujian dasar sensor infrared obstacle, pengujian response time sensor dengan komponen output dan pengujian sensitivitas komponen.

\section{Pengujian Dasar Sensor Infrared Obstacle}

Pengujian dasar sensor terdiri dari pengujian jarak deteksi sensor, pengujian pengukuran tegangan dan pengujian jenis obstacle. Pada pengujian jarak deteksi sensor ini bertujuan untuk memastikan jarak deteksi sensor agar sesuai dengan jarak yang ditentukan. Hasil pengujian ini dilihat pada tabel 1.

Tabel 1. Pengujian Jarak Deteksi Sensor

\begin{tabular}{cccccccc}
\hline Jarak & \multicolumn{7}{c}{ Sensor Infrared } \\
\cline { 2 - 7 }$(\mathbf{c m})$ & IR 1 & IR2 & IR3 & IR4 & IR5 & IR6 & IR7 \\
\hline 2 & Terdeteksi & Terdeteksi & Terdeteksi & Terdeteksi & Terdeteksi & Terdeteksi & Terdeteksi \\
3 & Terdeteksi & Terdeteksi & Terdeteksi & Terdeteksi & Terdeteksi & Terdeteksi & Terdeteksi \\
4 & Terdeteksi & Terdeteksi & Terdeteksi & Terdeteksi & Terdeteksi & Terdeteksi & Terdeteksi \\
5 & Terdeteksi & Terdeteksi & Terdeteksi & Terdeteksi & Terdeteksi & Terdeteksi & Terdeteksi \\
6 & Terdeteksi & Terdeteksi & Terdeteksi & Terdeteksi & Terdeteksi & Terdeteksi & Terdeteksi
\end{tabular}




\begin{tabular}{cccccccc}
7 & Terdeteksi & Terdeteksi & Terdeteksi & Terdeteksi & Terdeteksi & Terdeteksi & Terdeteksi \\
8 & Terdeteksi & Terdeteksi & Terdeteksi & Terdeteksi & Terdeteksi & Terdeteksi & Terdeteksi \\
& Tidak & Tidak & Tidak & Tidak & Tidak & Tidak & Tidak \\
9 & Terdeteksi & Terdeteksi & Terdeteksi & Terdeteksi & Terdeteksi & Terdeteksi & Terdeteksi \\
& Tidak & Tidak & Tidak & Tidak & Tidak & Tidak & Tidak \\
10 & Terdeteksi & Terdeteksi & Terdeteksi & Terdeteksi & Terdeteksi & Terdeteksi & Terdeteksi \\
\hline
\end{tabular}

Hasil pengujian menampilkan bawa sensor akan mendeteksi hingga jarak $8 \mathrm{~cm}$. setelah objek berada dijarak diatas $8 \mathrm{~cm}$ maka sensor infrared obstacle tidak akan mendeteksi adanya obstacle.

Pada pengujian pengukuran tegangan dibagi menjadi dua pengujian karena sensor infrared obstacle memiliki 2 kondisi yaitu HIGH atau kondisi saat sensor tidak mendeteksi adanya objek dan LOW atau kondisi saat sensor mendeteksi adanya objek.

\begin{tabular}{cccccccc} 
Q Tabel 2. Pengujian Pengukuran Tegangan Sensor Infrared Saat Kondisi HIGH \\
\hline \multirow{2}{*}{ Percobaan } & \multicolumn{7}{c}{ Tegangan (V) } \\
\cline { 2 - 8 } & IR1 & IR2 & IR3 & IR4 & IR5 & IR6 & IR7 \\
\hline 1 & 4.31 & 4.50 & 4.45 & 4.46 & 4.48 & 4.53 & 4.51 \\
2 & 4.31 & 4.50 & 4.45 & 4.46 & 4.48 & 4.53 & 4.51 \\
3 & 4.31 & 4.50 & 4.45 & 4.46 & 4.48 & 4.53 & 4.51 \\
4 & 4.31 & 4.50 & 4.45 & 4.46 & 4.48 & 4.53 & 4.51 \\
5 & 4.31 & 4.50 & 4.45 & 4.46 & 4.48 & 4.53 & 4.51 \\
6 & 4.31 & 4.50 & 4.45 & 4.46 & 4.48 & 4.53 & 4.51 \\
7 & 4.31 & 4.50 & 4.45 & 4.46 & 4.48 & 4.53 & 4.51 \\
8 & 4.31 & 4.50 & 4.45 & 4.46 & 4.48 & 4.53 & 4.51 \\
9 & 4.31 & 4.50 & 4.45 & 4.46 & 4.48 & 4.53 & 4.51 \\
10 & 4.31 & 4.50 & 4.45 & 4.46 & 4.48 & 4.53 & 4.51
\end{tabular}

Pada pengujian ini didapatkan angka yang stabil pada setiap pengujian dengan melakukan pengukuran tegangan ketujuh sensor menggunakan multimeter. Saat kondisi HIGH, Tegangan yang ditampilkan pada multimeter berada pada range $4 \mathrm{~V}$. Ketujuh sensor menghasilkan tegangan yang rata rata nya $4 \mathrm{~V}$ pada 10 kali percobaan. Hal ini berarti ketujuh sensor tersebut bekerja sesuai dengan standar tegangan karena sensor infrared obstacle FC-51 bekerja pada tegangan 3 sampai $5 \mathrm{~V}$.

Tegangan pada sensor infrared akan berkurang saat sensor tersebut sedang aktif atau ada sebuah objek yang terdeteksi oleh sensor atau kondisi LOW. Hasil tegangan tersebut dilihat pada Tabel 3.

Tabel 3. Pengujian Pengukuran Tegangan Sensor Infrared Saat Kondisi LOW

\begin{tabular}{cccccccc}
\hline \multirow{2}{*}{ Percobaan } & \multicolumn{7}{c}{ Tegangan (V) } \\
\cline { 2 - 8 } & IR1 & IR2 & IR3 & IR4 & IR5 & IR6 & IR7 \\
\hline 1 & 0.14 & 0.16 & 0.15 & 0.15 & 0.16 & 0.16 & 0.15 \\
2 & 0.14 & 0.16 & 0.15 & 0.15 & 0.16 & 0.16 & 0.15 \\
3 & 0.14 & 0.16 & 0.15 & 0.15 & 0.16 & 0.16 & 0.15 \\
4 & 0.14 & 0.16 & 0.15 & 0.15 & 0.16 & 0.16 & 0.15 \\
5 & 0.14 & 0.16 & 0.15 & 0.15 & 0.16 & 0.16 & 0.15
\end{tabular}




\begin{tabular}{cccccccc}
6 & 0.14 & 0.16 & 0.15 & 0.15 & 0.16 & 0.16 & 0.15 \\
7 & 0.14 & 0.16 & 0.15 & 0.15 & 0.16 & 0.16 & 0.15 \\
8 & 0.14 & 0.16 & 0.15 & 0.15 & 0.16 & 0.16 & 0.15 \\
9 & 0.14 & 0.16 & 0.15 & 0.15 & 0.16 & 0.16 & 0.15 \\
10 & 0.14 & 0.16 & 0.15 & 0.15 & 0.16 & 0.16 & 0.15 \\
\hline
\end{tabular}

Pengujian ini dilakukan dengan melakukan pengukuran tegangan ketujuh sensor pada saat sensor infrared mendeteksi adanya obstacle atau berada pada kondisi LOW. Tegangan yang ditampilkan pada multimeter berada dibawah $1 \mathrm{~V}$. Ketujuh sensor menghasilkan tegangan yang rataratanya $0.15 \mathrm{~V}$ pada sepuluh kali percobaan. Tegangan pada sensor infrared obstacle akan mengecil saat sensor mendeteksi adanya obstacle.

\begin{tabular}{|c|c|c|c|}
\hline No & $\begin{array}{c}\text { Bahan } \\
\text { Objek }\end{array}$ & Hasil & $\begin{array}{c}\text { Obstacle } \\
\text { LED }\end{array}$ \\
\hline 1 & Karet & Terdeteksi & Menyala \\
\hline 2 & Plastik & Terdeteksi & Menyala \\
\hline 3 & $\begin{array}{l}\text { Tangan } \\
\text { Manusia }\end{array}$ & Terdeteksi & Menyala \\
\hline
\end{tabular}

Pengujian ini bertujuan untuk memastikan apakah objek dengan bahan yang berbeda dapat terdeteksi oleh sensor infrared obstacle, dari ketiga objek dengan jenis bahan yang berbeda-beda yaitu objek berbahan karet, plastik dan objek berupa tangan manusia, ketiganya dapat terdeteksi oleh sensor infrared obstacle yang ditandai dengan lampu infikator yaitu Obstacle LED pada sensor yang menyala.

\section{Pengujian Response Time Sensor dengan Komponen Output}

Setiap komponen output yang dikendalikan oleh komponen input terdapat response time atau waktu tanggap, yaitu seberapa cepatnya komponen output bekerja saat sensor infrared obstacle dalam kondisi aktif atau sedang mendeteksi adanya obstacle. Pembahasan bagian ini meliputi tujuan pengujian, perangkat dan alat yang digunakan saat melakukan pengujian dan langkah-langkah pengujian yang dilakukan. Pengujian ini dilakukan sebanyak 10 kali percobaan pada setiap masingmasing sensor infrared obstacle. Tabel 5 menunjukan hasil pengujian response time yang telah dihitung rata-ratanya pada masing-masing sensor.

Tabel 5. Pengujian Response Time

\begin{tabular}{cc}
\hline $\begin{array}{c}\text { Sensor } \\
\text { Infrared }\end{array}$ & $\begin{array}{c}\text { Response Time } \\
(\mathbf{m s})\end{array}$ \\
\hline IR 1 & 2361 \\
IR 2 & 2171 \\
IR 3 & 2129 \\
IR 4 & 2180 \\
IR 5 & 2003 \\
IR 6 & 2044 \\
IR 7 & 2013 \\
\hline
\end{tabular}

Hasil pengujian menunjukan rata-rata response time dari ketujuh sensor infrared obstacle. Hasil tersebut berada pada angka disekitar 2 detik. walaupun hasil pengujian response time berbeda beda pada setiap percobaan, akan tetapi rata rata pengujian berada di rentang nilai yang hampir medekati yaitu 2 detik. Lamanya waktu response time dapat disebabkan oleh :

- Banyaknya jumlah komponen yang digunakan terutama jumlah sensor yang digunakan. 
- Penggunaan power dengan tegangan dan arus yang tidak kompatibel dengan Arduino atau dengan komponen komponen yang digunakan.

- Percobaan yang terlalu sering dan cepat saat meletakan objek didepan sensor infrared obstacle.

- Komponen output yang harus dikendalikan oleh sensor terlalu banyak.

\section{Pengujian Sensitivitas Komponen}

Pengujian sensitivitas komponen bertujuan untuk mengetahui tingkat sensitif komponen dan mengetahui apakah sensor sensor dapat mengendalikan komponen output dan dapat menerima perintah. Output dari pengujian ini dapat berupa hasil yang ditampilkan pada komponen - komponen itu sendiri. Alat yang dibutuhkan adalah Arduino Mega beserta semua komponen yang terdapat pada sistem pendeteksi tinggi dan antrian otomatis.

Tabel 6. Pengujian Sensitivitas Sensor

\begin{tabular}{cccccc}
\hline \multirow{2}{*}{ Objek } & \multicolumn{2}{c}{ Sensor } & \multicolumn{3}{c}{ Output } \\
\cline { 2 - 6 } & IR 1 & IR 2 & LED Green & LED Red & Pintu \\
\hline \multirow{2}{*}{ Pendek } & Tidak & Mendeteksi & Mati & Menyala & Tidak \\
& mendeteksi & & \multirow{2}{*}{ Terbuka } \\
Tinggi & Mendeteksi & Mendeteksi & Menyala & Mati & Terbuka \\
\hline
\end{tabular}

Tabel 6 menunjukan hasil deteksi dan hasil dari komponen output. Objek yang digunakan sebagai objek pendek berada pada tinggi dibawah $13 \mathrm{~cm}$, maka objek tersebut tidak akan sampai untuk berada diketinggian sensor infrared obstacle yang pertama yaitu $13 \mathrm{~cm}$. Sehingga objek hanya akan terdeteksi oleh sensor infrared obstacle yang kedua. Sedangkan objek tinggi digunakan objek dengan tinggi lebih dari sama dengan $13 \mathrm{~cm}$, maka objek tersebut dapat terdeteksi oleh sensor infrared obstacle yang pertama. Sehingga objek akan terdeteksi oleh sensor infrared obstacle yang pertama dan kedua.

Tabel 7. Pengujian Sensor Pada Kondisi Tertentu

\begin{tabular}{|c|c|c|c|c|c|}
\hline \multirow{2}{*}{ Kondisi } & \multicolumn{5}{|c|}{ Sensor } \\
\hline & IR 3 & IR 4 & IR5 & IR 6 & IR 7 \\
\hline $\begin{array}{l}\text { Masuk } \\
\text { Antrian }\end{array}$ & Mendeteksi & Mendeteksi & $\begin{array}{c}\text { Tidak } \\
\text { Mendeteksi }\end{array}$ & $\begin{array}{c}\text { Tidak } \\
\text { Mendeteksi }\end{array}$ & $\begin{array}{c}\text { Tidak } \\
\text { Mendeteksi }\end{array}$ \\
\hline Pintu Darurat & $\begin{array}{c}\text { Tidak } \\
\text { Mendeteksi }\end{array}$ & $\begin{array}{c}\text { Tidak } \\
\text { Mendeteksi }\end{array}$ & Mendeteksi & $\begin{array}{c}\text { Tidak } \\
\text { Mendeteksi }\end{array}$ & $\begin{array}{c}\text { Tidak } \\
\text { Mendeteksi }\end{array}$ \\
\hline $\begin{array}{l}\text { Masuk } \\
\text { Wahana }\end{array}$ & $\begin{array}{c}\text { Tidak } \\
\text { Mendeteksi }\end{array}$ & $\begin{array}{c}\text { Tidak } \\
\text { Mendeteksi }\end{array}$ & $\begin{array}{c}\text { Tidak } \\
\text { Mendeteksi }\end{array}$ & Mendeteksi & $\begin{array}{c}\text { Tidak } \\
\text { Mendeteksi }\end{array}$ \\
\hline $\begin{array}{l}\text { Wahana } \\
\text { Penuh }\end{array}$ & $\begin{array}{c}\text { Tidak } \\
\text { Mendeteksi }\end{array}$ & $\begin{array}{c}\text { Tidak } \\
\text { Mendeteksi }\end{array}$ & $\begin{array}{c}\text { Tidak } \\
\text { Mendeteksi }\end{array}$ & $\begin{array}{c}\text { Tidak } \\
\text { Mendeteksi }\end{array}$ & Mendeteksi \\
\hline
\end{tabular}

Tabel 7 Menunjukan hasil deteksi sensor infrared obstacle pada kondisi setelah pengujung yang telah memasuki antrian. Saat pengunjung telah melewati pintu masuk dan memasuki antrian maka pengunjung akan terdeteksi oleh sensor infrared obstacle yang ketiga dan keempat, sensor infrared obstacle yang ke-5 sampai ke-7 tidak mendeteksi karena pengunjung baru memasuki zona antrian sehingga tidak ada objek, maka sensor tersebut tidak mendeteksi adanya objek. Saat pengunjung ingin keluar melalui pintu darurat, maka pengunjung akan terdeteksi oleh sensor infrared obstacle yang kelima. Saat pengunjung ingin memasuki wahana, maka pengunjung akan terdeteksi oleh sensor infrared obstacle yang keenam, saat kondisi ini membuat sensor infrared obstacle yang ketujuh menjadi tidak mendeteksi karena sensor infrared obstacle yang ketujuh akan berada pada kondisi HIGH atau kondisi dimana sensor tidak akan mendeteksi objek. Saat wahana penuh yang membuat pengunjung yang telah keluar antrian harus masuk kembali ke antrian, maka pengunjung akan terdeteksi oleh sensor infrared obstacle yang ketujuh, saat kondisi ini membuat sensor infrared 
obstacle yang keenam menjadi tidak mendeteksi karena sensor infrared obstacle yang keenam akan berada pada kondisi HIGH atau kondisi dimana sensor tidak akan mendeteksi objek.

\section{KESIMPULAN}

Sistem pendeteksi tinggi dan antrian otomatis ini menggunakan Arduino Mega sebagai mikrokontroler, input berupa sensor infrared obstacle yang diatur dengan jarak deteksi yang kurang dari $10 \mathrm{~cm}$, dan output berupa Motor servo sebagai penggerak pintu yang berputar $90^{\circ}$, LED dan loudspeaker sebagai pemberi informasi pengunjung yang boleh masuk atau tidak, LCD dan seven segment sebagai tampilan informasi tentang jumlah antrian yang menampilkan digit angka 1 sampai 20.

\section{DAFTAR PUSTAKA}

[1] S.N. Aini, "Perancangan Wahana Rekreasi Anak Berbasis Edukasi Profesi Dengan Pendekatan Behavior Setting Di Batu". Universitas Islam Negeri Maulana Malik Ibrahim Malang, Jurusan Teknik Arsitektur. 2018.

[2] L. Maulana, dan D. Yendri, "Rancang Bangun Alat Ukur Tinggi Dan Berat Badan Ideal Berdasarkan Metode Brocha Berbasis Mikrokontroler". JITCE - VOL. 02 NO. 02, hal 76-84, 2018.

[3] Y. Firat \& T. Ugurlu, "Automatic Garage Door System with Arduino For defined licence plates of cars". 978-1-5386-6878-8/18. (C2018 IEEE, 2018.

[4] Internet : https://store.arduino.cc/usa/mega-2560-r3 [12 May 2020]. Store Arduino. ARDUINO MEGA 2560 REV3

[5] R. Pramana, dan R. Nababan, "Perancangan Perangkat Penghitung Jumlah Penumpang Pada Kapal Komersial Menggunakan Mikrokontroller". Jurnal Sustainable: Jurnal Hasil Penelitian dan Industri Terapan Vol. 08, No. 01, hal. 18- 29, 2019.

[6] B. Ramadan, dan M. Mujahidin, "Gerbang Penyeleksi Tinggi Badan Otomatis Pada Wahana Bermain Berbasis Arduino". UG Jurnal Vol. 9, No. 05, 2015.

[7] M. Ibtadaa, "LCD KARAKTER". Bandung : CNC Store Bandung, 2019.

[8] T. Arifani, dan A. Wulandari, "Smart Aquarium Berbasis Internet Of Things. Politeknik Negeri Jakarta, Jurusan Teknik Elektro", Prodi Broadband Multimedia, 2019.

[9] A.H. Lutfiyanto, dan A. Subari, "Rancang Bangun Pintu Wahana Otomatis Menggunakan Sensor Ultrasonik Hc-Sr04 Sebagai Pengukur Tinggi Badan Dan Sensor Load Cell Dengan Hx711 Sebagai Pengukur Berat Badan Berbasis Arduino Mega 2560”. GEMA TEKNOLOGI Vol. 19 No. 2, 2017.

[10] W. Hurisantri, "Sistem Pendeteksi Warna Dan Nominal Uang Untuk Penyandang Tuna Netra Berbasis Arduino Uno". Politeknik Negeri Sriwijaya, Jurusan Teknik Elektro, Prodi Teknik Telekomunikasi, 2016.

[11] L. Maulana, dan D. Yendri, "Rancang Bangun Alat Ukur Tinggi Dan Berat Badan Ideal Berdasarkan Metode Brocha Berbasis Mikrokontroler”. JITCE - VOL. 02 NO. 02, hal 76-84, 2018. 